\section{Diploma Course: "The Social Smoking Cost in the National Economy", A Necessary and Appliable Tool}

\section{Fé Fernández Hernández* and Efraín Sánchez González}

University of Medical Science of Havana, Faculty of Medical Science "10 de Octubre", Havana, Cuba

\begin{abstract}
Introduction: The smoking economic control is a prioritized strategic for the diminution of tobacco and cigarettes consumption. In the real Cuban context it evidence insufficient knowledge in economic subject by Public Health workers especially from the health workers related with the smoking control actions. In consequence it is necessary apply to the Superior Medical Education to contribute to a better professional education for the human resources related directly with the smoking control.

Objective: Create a diploma course about the smoking economic control.

Materials and methods: The teoricals methods used were the analysis and synthesis, the comparative and the inductive deductive. Like empiric method was used the bibliographic research.

Results: The diploma course "The smoking's social costs" is an answer from the necessity to improve the postgraduate formation from human resources hardly committed with the smoking control. This course explains smoking since a socioeconomic point of view with special emphasis in the social costs attributable to this risk factor. By itself the diploma course introduces an integral view of the smoking control and should be interesting for economists and accountants too.

Conclusion: The diploma course takes account the particularities from the health sector respect to the postgraduate education necessities about the smoking economic control. Also, the diploma structure is according to the regulations established for it.
\end{abstract}

*Corresponding author: Hernández FF, University of Medical Science of Havana, Faculty of Medical Science "10 de Octubre", Havana, Cuba, Tel: +53 78791313; E-mail: fefh@infomed.sld.cu

Citation: Hernández FF, González ES (2019) Diploma Course: "The Social Smoking Cost in the National Economy", A Necessary and Appliable Tool. J Community Med Public Health Care 6: 052.

Received: August 13, 2019; Accepted: August 23, 2019; Published: August 30 2019

Copyright: () 2019 Hernández FF and González ES. This is an open-access article distributed under the terms of the Creative Commons Attribution License, which permits unrestricted use, distribution, and reproduction in any medium, provided the original author and source are credited.
Keywords: Economic control; Postgraduate education; Smoking

\section{Introduction}

The often social changes, the globalization, the population ageing and the epidemiologic context are determining important transformations in the politic, social and economic context. This situation imposes new challenges to the Public Health like sector responsible for the save, guarantee and promotion of better life styles [1].

An important example about that is the smoking control. This risk factor is present in much of the no-transmissible illness. Also, it is an important cause of mortality in all social contexts. These are some of the mail reason by which the smoking control focuses a main attention from the Public Health [2].

The World Health Organization introduces the smoking economic control like main strategic across the MPOWER Program to insider in the diminution of the tobacco consumption. This is because of the own smoking characteristic like risk factor favors the application of economic policies for the smoking control $[2,3]$.

The smoking economic control in Cuba is weakening by the insufficient knowledge from the professional from the public Health front of economic arguments in favor to the tobacco and cigarettes sales. Also, the Cuban Public Health is limited by the difficult from the methods of estimation of smoking cost and the unknown of the smoking cost over the national economy [4-12].

This situation is in opposite position from the Public Health, the Cuban economies ministries and important international organizations like PAHO for example. These institutions apply or closer relations in favor to the smoking control where the economic control plays an important role [13-19].

It is important that the human resources from the health sector be sufficiently competitive to demonstrate the damages from smoking over the health and the economy too. By this way the health sector will be capable to suggest economics strategic for the smoking control and will gain in methodological and practical sufficiency advancing to a better smoking control [20-23].

To obtain that superiority in the postgraduate education it is necessary apply to the Superior Medical Education to contribute to a better professional education from the humans resources directly related with the smoking control. The strategies for the professional education are created with the objective of provide solutions to several problems emerged from the everyday life in the possible less time. These may obtain several qualitative changes since show the contradictions between the real context and the optimal context. That's why it is necessary a conscious planning process across actions focused to obtain the projected objective. These strategies can combine different forms of postgraduate education in correspondence to the main objective [24]. 


\section{Objective}

Create a diploma course about the smoking economic control.

\section{Materials and Methods}

The teoricals methods used were the analysis and synthesis, the comparative and the inductive deductive. Like empiric method was used the bibliographic research.

\section{Results}

In Cuba, Economy, Superior Education and Health must adopt a mutually positive position around the smoking economic control. For that, the research of smoking costs will create better social and academic conditions for a better smoking control.

The pre graduate forming of economists in Cuba don't include to the Health Economy like subject to research. By other side, the pre graduate forming in Health Science don't include to Health Economy neither. Also, the postgraduate forming in Health Economy is insufficient yet.

That's why the professional who be working for the smoking economic control and the smoking costs research must receive appropriate trainer courses which may obtain a higher knowledge homologation from the Health Economy and from this science contribute to a better research about the smoking costs and the smoking economic control [25].

The form of postgraduate education to create must go into depth of student abilities to gain efficiency using the economic tools in favor to the economic smoking control. The time to apply the strategic must be the necessary according to the main objective. Can't be less because it is necessary a sufficient time for the learning process. Neither must be longer because the knowledge obtained must be applied as soon as possible with touchable results. That's why the form of postgraduate education selected was the diploma course.

Like form of postgraduate education the diploma has the main objective of obtain the specialization in a special knowledge area and conduce to the acquisition of knowledge and academic, scientific and professional abilities in any step from the professional development according to the own professional necessities. The diploma course is composed by several courses related between them and finishes making a research to defend front of a panel of judges.

The diploma course "The smoking's social costs" is an answer from the necessity to improve the postgraduate formation from human resources hardly committed with the smoking control. This course explains smoking since a socioeconomic point of view with special emphasis in the social costs attributable to this risk factor. The whole diploma course is according to the real necessity of create general and particular strategies for the smoking control.

The diploma course is composed by 11 courses related between them. The system of subject planned is introduced in a way that the previous subject constitutes a precedent for the following subject. The courses 1, 2 and 3 are beginners respect to the smoking economic research. The courses 4 and 5 are focused on the direct cost attributable to smoking, the courses 6,7 and 8 are focused on the indirect cost attributable to smoking and the courses 9 and 10 are about the inequity attributable to smoking. Finally the 11 course is about the use of the economic policies for the smoking control. The diploma's container is displayed in the following table 1 .

The professional graduated will be capable to difference with high precision the economic responsibility of smoking in the society and the economy. It will be able to suggest specific and general strategies for the smoking economic control in the researched population. Also, will has available new knowledge that may be more critic and objective in the smoking economic control.

The form of postgraduate education introduced is contextualized because

1. is in correspondence with specific necessities from the health sector

2. is consequent with the national social policy

3. assist the teoricals and methodological forming for the smoking economic control

4. is flexible according to the order and the sequence of the contain

5. can be adapted to other context where be present the condition for the which was made

6. is feasibility the implementation of the diploma course.

These characteristics guarantee the needed methodological conditions for that the student can be benefited wholly from the diploma course.

Since itself the diploma course introduces an integral view from the smoking economic control. This particular form of postgraduate education can be interesting for economists and accountants too which must be agree with the principles of the smoking economic control. The main methodological fortitude is in the correspondence with the legal context from the Cuban postgraduate education and the Advanced Education too [26].

Although the student should has the opportunity to choose which course receive, it is recommendable receive all course to be benefited from the integral projection about smoking cost in the national economy subjected in the diploma course.

\section{Conclusion}

The diploma course takes account the particularities from the health sector respect the postgraduate education necessities' about the smoking economic control. Also, the diploma structure is according to the regulations established for it. 
Citation: Hernández FF, González ES (2019) Diploma Course: “The Social Smoking Cost in the National Economy”, A Necessary and Appliable Tool. J Community Med Public Health Care 6: 052.

\begin{tabular}{|c|c|c|c|c|c|}
\hline \multirow[b]{2}{*}{ Course } & \multirow[b]{2}{*}{ Container } & \multicolumn{4}{|c|}{ Time (hours) } \\
\hline & & Conference & Practice & \begin{tabular}{|l|} 
Private \\
research
\end{tabular} & Total \\
\hline 1 & $\begin{array}{l}\text { General epidemiologic clasification about risk factors. General description about adictions. } \\
\text { Economic characterization about smoking like risk factor. Double smoking economic effects. } \\
\text { Relation of smoking with thesocioeconomic behaviour of smokers. Cicle epidemiologic-economic } \\
\text { about smoking. }\end{array}$ & 16 & & 48 & 64 \\
\hline 2 & $\begin{array}{l}\text { The economy like determinat for the Public Health. Supporting the Public Health across the State } \\
\text { Budget. Relation between morbidity/mortality attributable to smoking and the Public Health } \\
\text { budget. The smoking impact over the State Budget. }\end{array}$ & 16 & 4 & 60 & 80 \\
\hline 3 & The Public Health costs. The smoking social impact. The social costs attributable to smoking. & 8 & & 24 & 32 \\
\hline 4 & $\begin{array}{l}\text { The illness protcol like a guide estimating the illness cost. Estimating the direct costs attributable } \\
\text { to smoking by the illness protocol. The illness burden like ratio for the illness direct cost. Method } \\
\text { for estimate the economic burden attributable to smoking. Limitations and potentialities of both } \\
\text { methods. }\end{array}$ & 24 & 4 & 84 & 112 \\
\hline 5 & $\begin{array}{l}\text { The importance of illness global burden in population researches. Limitations estimating the global } \\
\text { economic burden for smoking. Economic burden and epidemiologic burden attributable to } \\
\text { smoking. New formula to estimate the global economic burden for smoking. Algoritm to estimate } \\
\text { the glogal economic burden attributable to smoking. }\end{array}$ & 16 & 4 & 60 & 80 \\
\hline 6 & $\begin{array}{l}\text { The labor productiity lose like indirect cost for the morbidity/mortality. Socioeconomic } \\
\text { consequenes of the labor productivity lose. The labor productivity lose attributable to smoking } \\
\text { Clasifications. }\end{array}$ & 16 & & 48 & 64 \\
\hline 7 & $\begin{array}{l}\text { The earlier death like social and economic cost. Estimation the overmortality for smokers. Socal } \\
\text { cost in labor productivity lose because of earlier death in smokers. Socioeconomic impact from } \\
\text { the smokers earlier death in the HDR }\end{array}$ & 16 & 4 & 60 & 80 \\
\hline 8 & $\begin{array}{l}\text { The morbidity like labor absence cause's. Social cost because of labor absence. Labor } \\
\text { productivity losebecause of smoking in the worktime. The importance of workplace free of tobacco } \\
\text { smoke. }\end{array}$ & 16 & 4 & 60 & 80 \\
\hline 9 & $\begin{array}{l}\text { The socioeconomic inequity and the human development. Economic and social inequities related } \\
\text { with smoking. The consumption of cigarettes and tobaccos like main cause of the socioeconomic } \\
\text { inequity attributable to smoking. }\end{array}$ & 12 & & 36 & 48 \\
\hline 10 & $\begin{array}{l}\text { The Gini rate measuring the socioeconomic inequity. The socioeconomic inequity ratio from } \\
\text { smoking in the Public Health. Ratios of socioeconomic inequity by indirect costs attibutable to } \\
\text { smoking. }\end{array}$ & 4 & 8 & 36 & 48 \\
\hline 11 & $\begin{array}{l}\text { The fiscal policy like tool for the smoking control. Relation between smoking and the fiscal policy. } \\
\text { The cicle epidemiologic-economic of smoking and the fiscal policy. The iscal authorities role in the } \\
\text { smoking control. }\end{array}$ & 16 & 8 & 72 & 96 \\
\hline & TOTAL & 160 & 36 & 588 & 784 \\
\hline
\end{tabular}

Table 1: Diploma's container.

\section{References}

1. Franco-Giraldo Á (2016) Salud global: una visión latinoamericana. Rev Panam Salud Publica 39: 128-136.

2. Fonseca-Chaves PS, Méndez-Muñoz AJ, Bejarano-Orozco PJ, Guerrero-López MECM, Reynales-Shigematsu DLM (2017) Tabaquismo en Costa Rica: susceptibilidad, consumo y dependencia. Salud Pública de México 59: 30-39.

3. Blanco A, Sandoval MARC, Martínez-López L, Caixeta RB (2017) Diez años del Convenio Marco de la OMS para el Control del Tabaco: avances en las Américas. Salud Pública de México 59: 117-125.

4. González ES, Hernández FF (2017) Caracterización económica general del consumo de cigarrillos en Cuba de 2011 a 2013. Revista del Hospital Psiquiátrico de La Habana 14: 2.
5. Hernández FF, González ES Efraín (2017) Carga epidemiológica vs carga económica del tabaquismo por morbilidad. Rev Ciencias Médicas 21: 60-66.

6. García AP, Gálvez MGE, Friera EC, Carreño JCS, Sardiñas BNN (2016) Tabaquismo: valores e integralidad. Rev.Med.Electrón 38: 460-469.

7. Frómeta MM, Pimentel BFT, Silverio BM, Fernández IG, Toledo DT, et al. (2016) Labor extensionista desde la universidad médica para prevenir el tabaquismo en niños y adolescentes. EDUMECENTRO 8: 84-95.

8. Ávila NLP, Toledo SH, Lefrán AL (2016) Caracterización de las publicaciones sobre tabaquismo en revistas científicas cubanas (2005-2014). Rev Cubana Salud Pública 42: 375-384.

9. González ES, Hernández FF (2018) La relación entre la política tributaria y el control del tabaquismo en Cuba. CCM 22: 238-249. 
Citation: Hernández FF, González ES (2019) Diploma Course: “The Social Smoking Cost in the National Economy”, A Necessary and Appliable Tool. J Community Med Public Health Care 6: 052.

- Page 4 of 5 -

10. Martin ARM, Socarrás CJM, Guevara NCT, Ramos LLR, Márquez YHM (2015) Presencia de consumo de tabaco en un grupo de adolescentes. Gac Méd Espirit 17: 35-41.

11. González EMF, Oliva DAF (2018) Tabaquismo y su relación con las enfermedades cardiovasculares. Rev haban cienc méd 17: 225-235.

12. Pérez PV, Roche GG, Fogarty AW, Britton J (2015) Mortalidad por cáncer de pulmón y cardiopatía isquémica atribuible al tabaquismo pasivo en Cuba - 2011. Rev Cubana Hig Epidemiol 53.

13. Hernández FF, González ES (2017) Impacto del tabaquismo en el presupuesto sanitario de Cuba 1997-2014. Revista del Hospital Psiquiátrico de La Habana 14.

14. Hernández FF, González ES (2018) Algorithm to calculate the smoking economical burden in active and passive smokers. MOJ Toxicol 4: 373375

15. Hernández FF, González ES (2019) La carga económica del tabaquismo. España: Editorial Académica Española Pg no: 56.

16. González ES, Hernández FF (2016) La pérdida de productividad laboral atribuible al tabaquismo. Revista Cubana de Salud y Trabajo 17: 57-60.

17. González ES, Hernández FF (2018) Costo social por pérdida absoluta de productividad laboral. Revista Cubana de Salud y Trabajo 19: 33-39

18. Hernández FF, González ES (2019) Economic Inequity Attributable to Smoking Ratio's for the Public Health. Health Econ Outcome Res Open Access 4: 161
19. Hernández FF, González ES (2017) Pérdida de productividad por el consumo de cigarrillos en la jornada laboral. Revista Cubana de Salud y Trabajo 18: 9-12.

20. González ES, Hernández FF (2017) The role of fiscal authorities in the control of smoking. Rev Ciencias Médicas 21: 362-367.

21. Roche JRF, Moré SI, López ADG, Fundora WN (2014) Formación de capital humano para la prevención y atención de las adicciones. Educ Med Super 28.

22. Communist Party of Cuba (2017) Lineamientos de la política económica y social del partido y la revolución para el período 2016-2021. UNESCO, Pg no: 1-4.

23. MINSAP (2019) Red Cubana para el Control del Tabaquismo. Infomed Red de Salud de Cuba, Cuba.

24. Ledo MV, Perea RSS (2017) Fidel Castro y la docencia médica cubana. Educ Med Super 31: 277-286.

25. Rodríguez GF, Rodríguez CV (2016) Función de la economía de la salud en el proceso de actualización del modelo económico cubano. MEDISAN 20: 2175-2181.

26. Ministerio de Educación Superior (2005) Reglamento de la Educación de Postgrado. República de Cuba Pg no: 1-17. 


\section{Hit}

Journal of Anesthesia \& Clinical Care

Journal of Addiction \& Addictive Disorders

Advances in Microbiology Research

Advances in Industrial Biotechnology

Journal of Agronomy \& Agricultural Science

Journal of AIDS Clinical Research \& STDs

Journal of Alcoholism, Drug Abuse \& Substance Dependence

Journal of Allergy Disorders \& Therapy

Journal of Alternative, Complementary \& Integrative Medicine

Journal of Alzheimer's \& Neurodegenerative Diseases

Journal of Angiology \& Vascular Surgery

Journal of Animal Research \& Veterinary Science

Archives of Zoological Studies

Archives of Urology

Journal of Atmospheric \& Earth-Sciences

Journal of Aquaculture \& Fisheries

Journal of Biotech Research \& Biochemistry

Journal of Brain \& Neuroscience Research

Journal of Cancer Biology \& Treatment

Journal of Cardiology: Study \& Research

Journal of Cell Biology \& Cell Metabolism

Journal of Clinical Dermatology \& Therapy

Journal of Clinical Immunology \& Immunotherapy

Journal of Clinical Studies \& Medical Case Reports

Journal of Community Medicine \& Public Health Care

Current Trends: Medical \& Biological Engineering

Journal of Cytology \& Tissue Biology

Journal of Dentistry: Oral Health \& Cosmesis

Journal of Diabetes \& Metabolic Disorders

Journal of Dairy Research \& Technology

Journal of Emergency Medicine Trauma \& Surgical Care

Journal of Environmental Science: Current Research

Journal of Food Science \& Nutrition

Journal of Forensic, Legal \& Investigative Sciences

Journal of Gastroenterology \& Hepatology Research

Journal of Gerontology \& Geriatric Medicine
Journal of Genetics \& Genomic Sciences

Journal of Hematology, Blood Transfusion \& Disorders

Journal of Human Endocrinology

Journal of Hospice \& Palliative Medical Care

Journal of Internal Medicine \& Primary Healthcare

Journal of Infectious \& Non Infectious Diseases

Journal of Light \& Laser: Current Trends

Journal of Modern Chemical Sciences

Journal of Medicine: Study \& Research

Journal of Nanotechnology: Nanomedicine \& Nanobiotechnology

Journal of Neonatology \& Clinical Pediatrics

Journal of Nephrology \& Renal Therapy

Journal of Non Invasive Vascular Investigation

Journal of Nuclear Medicine, Radiology \& Radiation Therapy

Journal of Obesity \& Weight Loss

Journal of Orthopedic Research \& Physiotherapy

Journal of Otolaryngology, Head \& Neck Surgery

Journal of Protein Research \& Bioinformatics

Journal of Pathology Clinical \& Medical Research

Journal of Pharmacology, Pharmaceutics \& Pharmacovigilance

Journal of Physical Medicine, Rehabilitation \& Disabilities

Journal of Plant Science: Current Research

Journal of Psychiatry, Depression \& Anxiety

Journal of Pulmonary Medicine \& Respiratory Research

Journal of Practical \& Professional Nursing

Journal of Reproductive Medicine, Gynaecology \& Obstetrics

Journal of Stem Cells Research, Development \& Therapy

Journal of Surgery: Current Trends \& Innovations

Journal of Toxicology: Current Research

Journal of Translational Science and Research

Trends in Anatomy \& Physiology

Journal of Vaccines Research \& Vaccination

Journal of Virology \& Antivirals

Archives of Surgery and Surgical Education

Sports Medicine and Injury Care Journal

International Journal of Case Reports and Therapeutic Studies

Submit Your Manuscript: http://www.heraldopenaccess.us/Online-Submission.php 